\title{
How to increase technology transfers to developing countries: a synthesis of the evidence
}

\author{
ANA PUEYO ${ }^{*}$, MARÍA MENDILUGE², MARIA SANCHEZ NARANJO', JULIO LUMBRERAS 1 \\ 1 UPM-Escuela Técnica Superior de Ingenieros Industriales - Grupo de Organizacióm, Calidad y Medio Ambiente, Madrid, Spain \\ ${ }^{2}$ World Business Council for Sustainable Development, Geneva, Switzerland
}

The existing United Nations Framework Convention on Climate Change (UNFCCC) has failed to deliver the rate of low-carbon technology transfer (TT) required to curb GHG emissions in developing countries. This failure has exposed the limitations of universalism and renewed interest in bilateral approaches to $\Pi$. Gaps are identified in the UNFCCC approach to climate change TT: missing links between international institutions and the national enabling environments that encourage private investment; a non-differentiated approach for (developing) country and technology characteristics; and a lack of clear measurements of the volume and effectiveness of TTs. Evidence from econometric literature and business experience on climate change TT is reviewed, so as to address the identified pitfalls of the UNFCCC process. Strengths and weaknesses of different methodological approaches are highlighted. International policy recommendations are offered aimed at improving the level of emission reductions achieved through $\Pi$.

Keywords: business strategy; climate change; developing countries; economic models; technology transfer; UNFCCC

La Convention cadre des Nations Unies sur le changement climatique (CCNUCC) actuelle a échoué en ce qui concerne le taux de transfert des technologies sobres en carbone requises pour réduire les émissions de gaz à effet de serre (GES) dans les pays en développement. Cet échec a exposé les limites de l'universalisme et créé un regain d'intérêt pour les approches bilatérales au transfert de technologies. Des failles ont été identifiées dans la démarche de la CCNUCC par rapport au transfert de technologies: liens manquants entre institutions internationales et circonstances nationales favorables à l'investissement privé; une approche non différenciée entre pays (en développement) et les caractéristiques de la technologie; et un manque de clarté pour mesurer l'ampleur et l'effectivité des transferts de technologies. Les résultats de publications économétriques et d'expérience d'entreprises dans le transfert de technologies liées au changement climatique furent examinés, de manière à identifier et aborder les failles du processus de la CCNUCC. Les forces et faiblesses de différentes méthodologies furent mises en relief. Des recommandations de politique internationale sont faites dans le but d'augmenter le niveau de réduction d'émissions à atteindre grâce au transfert de technologies.

Mots clés : stratégie d'entreprise; changement climatique; pays en développement; modèles économiques; transfert de technologies; CCNUCC

\section{Introduction}

GHG emissions in developing countries are rising fast and are expected to continue to do so as these countries become the major global energy consumers. A global agreement to fight climate change cannot succeed if it does not address these increasing emissions. However, setting caps in some developing countries has met strong resistance, in view of the historical responsibility and the stronger capability of developed countries. Most developing countries consider economic and social development as their main priority and aim to raise their income per capita level before considering investments in 
expensive low-carbon technologies. Given this, the transfer of climate friendly technologies - adapted to country-specific development priorities - is perceived as a key element by the developing countries in achieving low-carbon development paths in the developing world.

Since its inception, the United Nations Framework Convention on Climate Change (UNFCCC) has recognized the importance of technology transfer (TT) in achieving stabilization of GHG concentrations. Since the Thirteenth Conference of the Parties (COP 13) in Bali, TT has also become one of the four pillars of an expected post-2012 climate change regime. Unfortunately, the UNFCCC process has become entangled in long discussions that have delayed action. The mechanisms it has so far created have either failed to materialize in actual TT or have led to progress on a project-by-project basis that cannot be scaled up to the level required. Businesses and developing country policy makers often complain about the large distance between the bureaucratic UNFCCC processes and their own actual and urgent needs.

The purpose of this article is to improve the understanding of the gaps in the UNFCCC approach to TT and to make policy recommendations based on the empirical evidence provided by the econometric, business and case study literature. The focus is on the transfer of mitigation technologies that are already available and avoids entering the debate on R\&D and innovation. In Section 2, the topic of TT is introduced and the inherent complexity of measuring and defining climate change TT is shown and discussed. The UNFCCC approach to TT to developing countries is reviewed in Section 3 , in which both a brief history of the process and a glimpse into the current status of the negotiations is provided. It assesses the effectiveness of existing UNFCCC mechanisms to promote TT and highlights the main shortcomings of the UNFCCC approach. An emerging body of econometric literature on climate change TT is reviewed in Section 4, and it is shown how it can contribute to solve some of the identified gaps. In Section 5, the practical stance of the business community, which is well placed to provide recommendations on specific country- and company-level policies that enhance $\mathrm{TT}$, is discussed. Finally, in Section 6, some policy recommendations are offered on how the UNFCCC process can be brought closer to the actual needs of both developing countries and the private sector, and some areas for further research are suggested.

\section{Defining and measuring climate change $T$}

The term 'technology transfer' has been defined and measured in many different ways by a wide range of disciplines (Mallett et al., 2009). In the field of climate change, the Intergovernmental Panel on Climate Change (IPCC) provides a frequently quoted definition of climate change TT as 'a broad set of processes covering the flows of know-how, experience and equipment for mitigating and adapting to climate change amongst different stakeholders such as governments, private sector entities, financial institutions, non-governmental organizations, and research or education institutions' (IPCC, 2000 ). Under this broad definition, TT could provide a recipient country with the capacity to install, operate, maintain and repair imported technologies, produce lower-cost versions of imported technologies, adapt imported technologies to domestic markets and circumstances, and develop new technologies, while respecting relevant intellectual property rights (IPR) (UNFCCC, 2009a).

Several authors have noted that these diverse aspects of TT convey different impacts on the recipient firm or country (Wei, 1995; Bell, 1997; Mallett et al., 2009). Three flows of transferred technological content are subsequently defined, from lower to higher impact on the technological capabilities of the recipient. The first flow encompasses capital goods and equipment; it increases the production capacity of the recipient, but on its own does not enable the recipient to efficiently use the imported facilities or to generate technological change. The second flow includes skills and know-how for 
operating and maintaining equipment. It places the human resources of the importer at the technological level required to efficiently operate the imported technology but without indigenous efforts, it does not enable technological change. The third flow encompasses knowledge and expertise for generating and managing technological change. It creates new technological capacity by both the transfer itself and the active, independent learning, creation and innovation of the recipient.

Several classifications and lists of relevant technologies for climate change mitigation are reviewed by Brewer (2009). Technologies can be transferred through several channels, mainly trade, foreign direct investment (FDI) in the form of either wholly owned subsidiaries or joint ventures, licensing agreements, official development assistance (ODA), hiring of foreign human resources, and person-to-person pathways such as training programmes, conferences or scientific exchanges.

Measuring TT is intrinsically difficult given the diverse and complex ways in which transfers occur and because technology has no measurable physical presence or well-defined price (IPCC, 2000). Rather, technology is embodied in products, intermediate inputs and processes (World Bank, 2008). Consequently, most economic literature has used indirect techniques to measure technology, such as total factor productivity (TFP), or indexes that emphasize inputs into technological achievement such as education levels, numbers of scientists and engineers, expenditures on R\&D or on R\&D personnel, or the number of patents granted. A review of these different techniques can be found in Archibugi and Coco (2004). In the field of climate change, the IPCC (2000) recommends the use, with caution, of several types of international financial flows as indicators of both levels of international TT and how these levels change over time. Among the main types of financial flows are ODA, loans at market rates, FDI, trade, foreign portfolio equity investment (FPEI) and venture capital. These flows, however, do not cover all the potential TT channels previously defined. Furthermore, they cannot be taken as an indication of the level of skills and knowledge that have been transferred alongside financial flows (Mallett et al., 2009).

\section{The UNFCCC approach to TT}

\subsection{Status of $\mathrm{TT}$ in the international climate change negotlations}

TT is an important element of the UNFCCC and is included in several of its articles (mainly Articles 4.1 , 4.3, 4.5 and 4.7). Indeed it has been part of the agenda in each of the Conference of the Parties (COP) so far. Since its adoption in 1992, the UNFCCC approach to TT has been based on two major assumptions:

- Developed country Parties have the capacity to undertake research, development, deployment and transfer of technologies (Article 4.5), while developing country Parties are seen as recipients of technologies, know-how and finance as a precondition for action (Article 4.7).

- Developing country Parties require broad technological support from developed country Parties, to include the transfer of equipment and know-how, and the development and enhancement of endogenous capacities and technologies (Article 4.5).

At COP 13 (held in Bali), technology was identified as one of the four building blocks for a future climate change regime as outlined in the Bali Action Plan. COP 15, held in Copenhagen in 2009, failed to deliver the new binding and ambitious international climate agreement outlined in Bali. Instead, it contributed to a fracturing of the static UNFCCC preconceptions about the developing world and to revealing new structures of power (Grubb, 2010), with China, India and Brazil playing a prominent role in drafting the non-binding Copenhagen Accord. COP 15 also illustrated the limitations of multilateral treaties for securing consensus on mitigation commitments, thus leading to a 
renewed interest in bilateral agreements and small group agreements including the most powerful countries. ${ }^{1}$

However, some progress in the area of technology was achieved in Copenhagen. The Copenhagen Accord proposed a Technology Mechanism (TM) as the basis for subsequent negotiations, with the aim to accelerate technology development and transfer in support of action on adaptation and mitigation that will be guided by a country-driven approach and be based on national circumstances and priorities' (UNFCCC, 2010b, Decision 2/CP.15, Article 11). This new institution was mainly advocated by developing countries, specifically the members of G77 and China, while the preference of Annex I countries was to use or modify existing institutions (Staley and Freeman, 2009). Financial support was also mentioned in the Copenhagen Accord, with US $\$ 30$ billion designated in fast-track funding from developed to developing countries for the period 2010-2012 and the creation of a Green Fund mobilizing US $\$ 100$ billion a year by 2020. However, it was not made clear which part of these funds would be available for TT.

The Cancun Agreements, achieved at COP 16 in December 2010, have brought the Copenhagen Accord under the auspices of the UN with the approval of the 193 countries working under the UNFCCC itself. Much work still needs to be done to establish a comprehensive long-term framework for controlling GHG emissions, particularly on the definitions of emission reduction targets and timetables. Even so, significant outcomes have been achieved, including the decision to establish a TM that contains a Technology Executive Committee and a Climate Technology Centre and Network. The objective of the TM is to enhance clean technology development and diffusion. Funding availability for the TM, as well as the mechanism to allocate these funds, is still under discussion, and the eligibility criteria for countries and technologies have not yet been addressed.

Despite some differences between the views of developing and developed countries regarding the impact of IPR in TT, there was no mention of IPR in the final text approved in Cancun. This implies that the issue was a negotiating tactic rather than a real problem. Indeed, IPR were not central to any country proposals. However, developing and developed countries have offered passionate views on this matter. Developed countries considered IPR as essential to promote innovation. In contrast, some developing countries proclaimed that IPR deter TT and proposed compulsory licensing of certain clean technologies (this was defended by China and India). Still, some of the emergent economies softened their stance towards IPR as they increased their ownership of climate change technologies (Staley and Freeman, 2009)

Throughout the negotiations, the significant role of the private sector and the need for policy reforms in developing countries to encourage private investment has been stressed by developed countries. Developing country submissions to the UNFCCC negotiations have instead focused on the request that developed countries meet their responsibility and provide finance and technology (WRI, 2009; Marcellino and Gerstetter, 2010). Annex IV of the Cancun Agreements mentions that the Technology Executive Committee should seek input from the private sector and civil society. This has moved the need to include the private sector from the main text of the Bali Action Plan to an Annex, which suggests that it is not considered a priority.

\subsection{Effectiveness of the existing UNFCCC $T$ catalysts}

The UNFCCC has used three main types of catalyst for climate change TT to developing countries:

- Institutions, namely the Expert Group of Technology Transfer (EGTT)

- Creation and diffusion of information through Technology Needs Assessments (TNA) and the technology transfer information Clearing house (TT:CLEAR) 
Financial vehicles, such as the Global Environment Facility (GEF) and the Clean Development Mechanism (CDM)

The EGTT was created in 2001 to report to the Subsidiary Body for Technological and Scientific Advice with the objective of enhancing the implementation of Article 4.5 of the UNFCCC, by, inter alia, analysing and identifying ways to facilitate and advance TT activities. In Bali, the EGTT was also asked to report to the Subsidiary Body for Implementation and given the task of preparing reports on performance indicators (UNFCCC, 2009b), financial needs (UNFCCC, 2009a) and future strategy (UNFCCC, 2009c). At the request of the G77 and China (IISD, 2006), a new TM was considered in the Copenhagen Accord, and it was decided in the Cancun Agreements that it would succeed the EGTT.

TNA is a systematic approach to 'identify, evaluate, and prioritise technological means for achieving sustainable development in developing countries, increasing resilience to climate change, and avoiding dangerous anthropogenic climate change' (UNDP, 2009). TNA are country-driven activities, undertaken within the UNFCCC and supported by the GEF, the United Nations Development Programme (UNDP) and the United Nations Environment Programme (UNEP) as funders and coordinators.

The CDM was created by the Kyoto Protocol (1997) to first reduce the cost of compliance for Annex I countries by taking advantage of cheaper emission reduction opportunities in non-Annex I Parties and, second, to support sustainable development in non-Annex I host countries. The GEF is the financial mechanism of the UNFCCC, as well as other UN Conventions, and provides grants to developing countries, and countries with economies in transition, for projects related to biodiversity, climate change, international waters, land degradation, the ozone layer, and persistent organic pollutants. Although neither the CDM nor the GEF were created with the aim of funding TT, they have nevertheless done so indirectly.

A summary of the main achievements and pitfalls of these mechanisms in the promotion of TT appears in Table 1.

\subsection{Main gaps of the current UNFCcC approach to TT}

The new TM decided in the Cancun Agreements could potentially achieve higher rates of TT to developing countries if the three main gaps in the current UNFCCC approach are addressed.

First, the UNFCCC deals with TT as a government-to-government process, urging developed country Parties to support technological development in developing country Parties (Article 4.5) and providing guidelines (in the form of a TNA handbook) to the latter on how to prioritize technological means for achieving low-carbon development paths. However, no significant efforts have been made to engage the private sector in the definition of an effective technology policy (UNCTAD, 2010; WBCSD et al., 2010), which neglects the key role of the private sector as the owner of most climate change mitigation technology and as the sector responsible for most international TT through trade and FDI (IPCC, 2000; Stern, 2007; Brewer, 2009; World Bank, 2009).

The UNFCCC process appears disconnected from the enabling frameworks that facilitate private investment and, until recently, no attempts were made to understand strategic business decisions regarding TT. On the one hand, the existing instruments to promote TT (EGTT, TNA, CDM, GEF) are not integrated into national planning processes. When the existing instruments are used in specific $\mathrm{TT}$, it is done on a project basis and does not permeate into the rest of the economy. These mechanisms seem insufficient to remove existing barriers, leverage a large scale of private investment or promote endogenous technologies in developing countries. The updated TNA handbook recognizes the need to step away from the project-based approach and considers TT in light of long-term visions 
TABLE 1 Effectiveness of UNFCCC mechanisms to promote TTS

\begin{tabular}{l} 
Instrument $\quad$ Achievements \\
\hline EGTT \\
$\begin{array}{l}\text { Improvement of the understanding of financial and } \\
\text { capability gaps to enhance } T \text { through a number of } \\
\text { reports and workshops } \\
\text { Enhanced dialogue with the private sector since } 2009\end{array}$
\end{tabular}

TNA

CDM

proposals and ideas

- Identification of in-country capacily gaps in developing countries

- Attempt to turn proposals into specific projects through a recent call for proposals for $T T$ pilot projects

- Forty per cent of CDM projects (1516 projects)
Pitfalls

- Members are political appointees instead of experts in T, IPR or clean technologies (South Center and CIEL, 2008)

Considered by the $\mathrm{G} 77$ plus China as a mere fact-finding mechanism that has delayed hard but necessary decisions to enhance TT (IISD, 2006)

- Lack of clarily of the institutional design or funding of the new TM replacing the EGTT may render it fulile in enhancing $\Pi$

- No projects or programmes from the TNAs have yet been implemented accounting for $59 \%$ of estimated emission reductions (roughly $335 \mathrm{MtCO}_{2} / \mathrm{yr}$ ) claim to involve $T^{\mathrm{a}}$ (Seres et al., 2010)

- The CDM has contributed to technology diffusion, reducing the payback period and improving the internal rate of return (IRR) of clean technology projects (Hansen, 2008; Ang, 2009)
Lack of coordination between the TNA process and national planning processes

- Absence of a systernatic approach for financing

- Data on funding and emission reductions of CDM projects involving $\Pi \mathrm{T}$ are nol systematically collected

- Quality of CDM TT is not systematically assessed; $T$ quality can be defined as the degree to which it raises the recipient's technological know-how and capacily to innovate (Popp, 2008; Schneider el al., 2008)

- Finance flows channelled by the CDM account for a small share of the estimated funding needed to reduce emissions in developing countries (UNFCCC, 2010a)

- Some of the reductions achieved by the CDM are not 'additional', meaning that they would have happened anyway and should not be financially supported (Wara, 2009)

- The CDM only contributes to diffuse technologies at the later stages of maturity, with a low-risk profile

- CDM financing has not filled the gaps left by the private sector, concentrating in China, India and Brazil and in low-risk technologies (UNEP Risoe, 2010)

- The project-based nature of the CDM does not foster large-scale deployment of miligation technologies or the promotion of innovation in host countries (Staley and Freeman, 2009) 
TABLE 1 Continued

\begin{tabular}{lll} 
Instrument & Achievements & Pilfalls \\
\hline GEF & $\begin{array}{l}\text { A significant share of the budget is allocated to } \\
\text { projects in least-developed countries and innovative } \\
\text { technologies (Peterson, 2008) }\end{array}$ & $\begin{array}{l}\text { Small budget (US\$190 million in 2009) compared to } \\
\text { CDM financing and to other funds }\end{array}$ \\
& $\begin{array}{l}\text { Most emission reductions achieved in big projects in } \\
\text { China, Brazil, India and Russia, therefore, not filling }\end{array}$ \\
& the gaps left by the private sector (Peterson, 2008)
\end{tabular}

Notes: 'The data in Seres et al. (2010) regarding TT in CDM projects rely on TT claims made by project participants in the Project Design Documents (PDDs) ol $\mathbf{4 9 8 4}$ projects in the CDM pipeline as of 30 June 2010 . Only those projects, lor which it is explicitly stated in the PDD whether or not TT is expected, are considered in the calculation ol percentages. These claims are subject to uncertainty as they are not based on a common definition ol $T T$ and they have not gone through verification (unless they belong to the additionality test). Also, they reler to projects often at the design stage, which may not be successlully implemented and hence may not deliver emission reductions.

(UNDP, 2009). On the other hand, the absence of an agreement after the COPs in Copenhagen and Cancun regarding globally binding emission reduction targets and the slowness and inefficiency of the international climate change negotiations has not provided the necessary strong signals to stimulate private sector investment in low-carbon technologies in developing countries.

Second, the UNFCCC discourse is based on a North-South TT paradigm that divides the world into two blocks: technologically active and technologically passive (Brewer, 2008; Cannady, 2009). Observation of actual technology flows shows that this simplistic paradigm no longer holds. In an increasingly interconnected world, a group of large and dynamic developing countries are actively absorbing foreign technologies and developing and transferring endogenous ones.

FDI data compiled in the World Investment Report 2010 (UNCTAD, 2010) show that over a quarter of greenfield investments in alternative/renewable power generation were placed in developing economies. Nearly $10 \%$ of renewable power generation investment projects were made by transnational companies (TNCs) from developing countries, the bulk of which are South-South. More illustrative is the case of greenfield investments in the manufacturing of environmental-technology products such as wind turbines, solar panels or biodiesel plants. Developing economies attracted nearly half of the projects in this industry over the period 2003-2009 and have surpassed developed countries in the last 2 years (UNCTAD, 2010). Still, performance across developing countries is highly unequal with most investment concentrated in China, India and Brazil, part of the so-called BRIC economies. ${ }^{2}$ China and India host nearly $20 \%$ of the world's wind power generation capacity (World Bank, 2009) and are world leaders in a variety of climate-friendly technologies.

The diverse performance of the CDM in developing countries reflects a similar pattern to FDI. China has the highest concentration of CDM projects, distantly followed by India and Brazil. As of June 2010 , these three countries held $72 \%$ of the CDM projects and $77 \%$ of the associated GHG emission reductions (UNEP Risoe, 2010), while African countries and least developed countries (LDCs) were largely absent. As regards TT as facilitated by the CDM, a recent study showed that China, India and Brazil have a lower than average TT rate than the rest of the host countries (Seres et al., 2010). While BRIC countries use predominantly local knowledge or equipment, the remaining host countries are more dependent on foreign technology to implement CDM projects. The same study showed that nonAnnex I countries supply technology to $15 \%$ of the CDM projects involving TT. China is among the top five technology suppliers, ahead of many developed economies, while India and Brazil also hold a significant share (Seres et al., 2010). These figures show that the UNFCCC mechanisms have not addressed 
the specific needs of different developing countries and have instead replicated geographic patterns of trade and FDI flows.

Third, efficient mechanisms for monitoring, reporting and verification (MRV) the magnitude and effectiveness of climate change TT to developing countries are not available, which is an unresolved issue in the negotiations. While developing countries focus their call for an MRV mechanism on the need for compliance mechanisms that include TT, developed countries believe such a mechanism will be key to defining the eligibility criteria for Nationally Appropriate Mitigation Actions (NAMAs). The future TM will need to define a set of criteria to assess the effectiveness of TT activities.

\section{Econometric studles of climate change TTs}

\subsection{Theoretical framework: the economics of technology diffusion}

The field of the economics of technology diffusion, reviewed by Keller (2004) and Saggi (2004), provides the theoretical basis for the econometric study of climate change TT.

In the field of the economics of technology diffusion, it is realized that foreign sources of technology are of dominant importance for domestic productivity growth and that there are big differences in how effective countries are in adopting foreign technology. One of its main aims is to identify the major determinants of successful TT. This is usually measured as growth in TFP as a result of foreign technology spillovers. Differences in the bilateral speed of diffusion would explain the greater effect of foreign R\&D in the domestic TFP of some specific economies.

Keller (2004) summarizes the theoretical framework of technology diffusion using a straightforward linear model that explains the productivity of a country in terms of its stocks of domestic and foreign technology. A number of econometric studies have attempted to estimate the foreign technology elasticity of productivity, whereby indicators of foreign R\&D act as proxies for the foreign stock of technology, channels of diffusion and domestic absorptive capacity. Evidence shows that country size is an important determinant of the relative importance of foreign versus domestic technology sources (Eaton and Kortum, 1999). Foreign sources of technology are more important for small and relatively poor countries, given the size difference in domestic $R \& D$ investments. However, controlling for size, the smaller and poorer a country is, the more intensively it relies on domestic technology sources to increase its productivity, which shows the importance of the 'distance to the frontier' (Keller, 2004). The success of countries in transforming foreign knowledge into domestic productivity is also explained by how their firms engage in international economic activities, mostly through importing (Coe and Helpman, 1995; Xu and Wang, 1999; Eaton and Kortum, 2002; Lee, 2009; Liao et al., 2009) and FDI (Xu, 2000; Ramondo, 2009; Vadlamannati and Tamazian, 2009). Finally, the effectiveness in adopting foreign technology accessed through international economic activities depends on absorptive capacity, which itself is determined by human capital and domestic R\&D spending (Borensztein et al., 1998; Kuo and Yang, 2008; Xu, 2008; Blalock and Gertler, 2009; Yin and Ding, 2009).

Econometric studies have also analysed the impact of trade, foreign investment and IPR national policies on technology diffusion. Trade liberalization needs to be complemented by appropriate policy measures with respect to human capital and local R\&D to deliver positive TT effects (Saggi, 2004). Restrictions to FDI can lower the quality of transferred technologies (Mansfield and Romeo, 1980; Kabiraj and Marjit, 1993; Javorcik and Spatareanu, 2008). On the other hand, FDI incentives are not always effective. They do not increase the rate of FDI beyond business-as-usual for investments geared towards the domestic market, which are instead driven by strong fundamentals in the host economy (Hines, 1996; Devereux and Griffith, 1998). Finally, as regards IPR policies, initial theoretical studies have concluded that strong IPR protection is not favourable to the South (Helpman, 1993; 
Glass and Saggi, 2002). However, a more extensive body of empirical research shows that weak IPR protection deters FDI and knowledge spillovers to developing countries, forcing multinational companies (MNC) to keep production at home (Ferrantino, 1993; Lee and Mansfield, 1996). A recent paper by Dinopoulos and Segerstrom (2010) has shown that stronger IPR protection in the South leads to an increase in the rates of TT within MNC and in R\&D employment by southern affiliates of northern MNC, a decrease in the North-South wage gap, and a temporary increase in the northern innovation rate.

\subsection{Econometric literature}

Econometric literature on climate change TT is concerned not with the impact of foreign technologies on a country's productivity, but instead with a country's absolute or relative $\mathrm{CO}_{2}$ emissions and its energy intensity. Two kinds of economic relationship are measured in the literature: first, the impact of recipient country characteristics on the magnitude or likelihood of foreign climate change technology flows received and, second, the impact of foreign technology flows on $\mathrm{CO}_{2}$ emissions or energy intensity of the recipient country.

\subsubsection{Recipient country characteristics and foreign flows of climate change technology}

Disaggregated data on import flows or FDI related to climate change technologies are not available for most developing countries, which prevents their use as proxy variables for international TT. Instead, many studies have measured these flows through the TT claims in CDM projects (Dechezleprêtre et al., 2008; Doranova, 2009; Seres et al., 2009, 2010) or the number of filed foreign patents related to climate change technologies (Hascic and Johnstone, 2009; Dechezleprêtre et al., 2010).

The dependent variables in these studies (existence of TT in a specific CDM project or number of foreign patents filed) reflect intentions to provide foreign technologies to developing countries, rather than their actual use and subsequent knowledge spillovers. For example, in the CDM, many projects included in the models are at the design stage. Their TT claims are ex ante and only indicate that sourcing of foreign equipment or knowledge is expected. No information is provided about the transfer process, its success in leading to knowledge spillovers, nor the role of local absorptive capacity in maximizing these. On the other hand, while patents express the intention to use an exclusive right over a technology in a given country, this does not mean that the owner will actually do so and does not reflect the extent of the associated emission reductions when the technology is actually implemented.

Dechezleprêtre et al. (2010) define a comprehensive model where the dependent variable is the flow of climate change inventions between inventor and recipient countries, proxied as the number of climate change-related patents from the inventor filed in the recipient. The explanatory variables are the accumulated knowledge in the recipient country, the cost of technology diffusion between country pairs, the cost of adopting local inventions, the cost of diffusion from other countries and the demand for technology in the recipient country. Results show that the accumulated knowledge in the recipient country is significant and positive when measured as technology-specific knowledge instead of the general educational level of the population. The implementation costs of technology have a significant and negative impact in most regressions when measured as either weak IPRs, tariffs, as not belonging to the same trade block, or as not sharing a common language. As expected, general demand variables such as income per capita and population have a positive significant impact. Most technology-specific demand variables such as the production of renewable energy, winter temperature or the number of cars are also significant and positive.

Haščič and Johnstone (2009) present similar results in terms of the importance of specific absorptive capacity, trade openness, and demand size and growth. Although they use a less comprehensive model, 
they introduce policy variables to explain technology diffusion using patent data. They conclude that commitment to climate change mitigation has a positive and significant influence on TT in a model with only Annex I countries. Also, the degree of involvement in CDM activities, per pairs of countries, is significant and positive for countries that have established the necessary institutions.

Dechezleprêtre et al. (2008) use a logit model to explain the likelihood of CDM projects receiving TT for a dataset of $644 \mathrm{CDM}$ projects registered as of May 2007. The model tests the importance of project and host country characteristics in determining the likelihood of TT in a specific CDM project. Results show that, keeping all other explanatory variables constant, larger and more wealthy developing countries are less likely to need TT to implement CDM projects. On the other hand, CDM projects in countries with high economic growth are more likely to involve TT. The impact of technological capabilities on the likelihood of TT is ambiguous depending on the type of technology used by the project. In the energy and chemicals sectors, high capabilities improve the likelihood of TT, implying that a significant knowledge base is necessary to adopt the new technologies. In agriculture and waste management, high capabilities reduce the likelihood of TT, meaning that the technologies are already available locally. These results suggest that the level of technological development determines the availability of endogenous technologies. Countries with higher capabilities, who are able to adopt foreign mature technologies and develop a domestic technological base, would thus only need to transfer the newest technologies. However, the conclusions of Dechezleprêtre and colleagues were based on CDM experience at a time when the project portfolio was largely dominated by large-scale projects in China, with hardly any African or LDC projects. Therefore, no valid inference can be made regarding the factors that influence TT in these areas.

A recent report by Seres et al. (2010) about the CDM contribution to TT uses a more extensive data set of 4984 CDM projects in the pipeline (registered or under validation) as of June 2010 . The model uses 3778 of these projects that explicitly state if they will or will not involve TT. Seres and colleagues conducted a regression analysis in two stages. First, they built a logit model to predict the probability of TT for different combinations of project type, host country and year. Second, they constructed an equation that relates the predicted probabilities to country characteristics. The results calculated using this equation show that TT in CDM projects is more likely in countries with a small population and a low technical capacity, where technical capacity is measured as the discounted stock of patents issued, confirming some of the previous findings in Dechezleprêtre et al. (2008).

\subsubsection{Foreign technology flows, energy intensity and carbon emissions}

A second group of studies is concerned with the relationship between foreign economic flows (received mostly through FDI, trade, licensing or ODA as proxies for technology diffusion) and changes in energy intensity, carbon intensity or emissions per capita as proxies for knowledge spillovers (Frankel and Rose, 2002; Mielnik and Goldemberg, 2002; Cole and Elliott, 2003; Cole, 2006; Ang, 2009; Hübler and Keller, 2010). In these studies, the aggregated effect of foreign activity is analysed, and they do not therefore capture the specific effect of climate change-related technologies. This is mostly due to the unavailability of historic data on climate change-related financial flows for most countries.

A negative impact of foreign activity on the carbon or energy intensities (emissions or energy consumption relative to GDP) of the recipient country might be expected as a result of the transfer of more efficient technologies. However, the empirical results do not justify this expectation because foreign economic flows actually encompass three different effects, not all related to TT, on the carbon or energy intensity of the recipient country: scale, composition and technique effects. The scale effect suggests that higher energy use and higher GHG emissions result from an increase in foreign economic 
activity (Peterson, 2008). The scale effect is only relevant when carbon emissions or energy consumption is measured in absolute terms. The composition effect, on the one hand, implies that foreign inflows may change the industrial structure of an economy with positive or negative consequences depending on country circumstances. For example, countries with lax environmental regulations or high capital-to-labour ratios may attract pollution-intensive activities, raising energy use and emissions. On the other hand, economic development leads to structural shifts, first from agriculture to industry (leading to higher emissions), and then from industrial to service activities, or from heavier to lighter industry, both of which lead to emissions reductions. Therefore, the way the composition effect is realized depends on specific country circumstances. The technique effect has a direct and indirect effect on GHG emissions reductions. The direct effect comes from increased openness to the diffusion of cleaner and efficient production methods, which relates to TT. The income-induced indirect effect happens as openness leads to increased wealth and a rising demand for stricter environmental regulations, which also encourages cleaner technologies. This income-induced indirect effect is compatible with the literature on Kuznets' environmental curve, which predicts an inverted U relationship between per capita income and pollution. Some authors claim that the translation of wealth into higher environmental conscience, and subsequent environmental regulation, happens more clearly in democratic societies (Frankel and Rose, 2002).

The few studies that have attempted the econometric study of knowledge spillovers through foreign low-carbon technologies have been mostly concerned with isolating the direct technique effect of foreign activity from both the indirect technique effect and scale and composition effects. The scale effect is usually neutralized by using variables relative to income levels (i.e. carbon intensity) instead of gross variables. The composition effect is modelled through indicators of the country's economic structure, such as the capital-to-labour ratio or the share of industrial value added in GDP. Finally, the indirect technique effect can be modelled by introducing income per capita variables.

Hübler and Keller (2010) built a model to explain time changes in the energy intensity of a set of countries by their foreign financial flows (FDI, imports and ODA), income per capita, GDP share of industrial value added and GDP share of total investments. The model shows an insignificant effect of FDI, imports, income per capita and GDP share of industrial value added. However, ODA flows are significant and negative, which is in line with the expectation that industrialized donor countries promote clean technologies in developing countries. The investment share of GDP is significant and positive, which indicates that rising investments lead to more energy-intensive processes. In any case, the model does not find a robust energy reducing effect of FDI and imports. The authors interpret this as indicating that the effects of FDI inflows on energy use depend on country-specific characteristics and policies, which cannot be captured at a macro level. Besides, the use of aggregated FDI precludes both the identification of the particular effect of low-carbon technology-related FDI and isolating it from the composition effect of FDI related to energy-intensive production.

Cole and Elliott (2003) define a model to explain the effect of trade on emissions per capita and per unit of GDP of various pollutants, including $\mathrm{CO}_{2}$. Their analysis suggests that the relationship between trade liberalization and $\mathrm{CO}_{2}$ emissions per capita or income depends on country characteristics other than income and factor endowments. A significant and negative coefficient of the time trend for emissions per capita indicates that factors common to all countries that change over time, such as technological advances, are reducing emissions.

Another attempt to model the effect of trade on $\mathrm{CO}_{2}$ emissions is provided by Frankel and Rose (2002), who use income per capita and its square, trade openness (an index of democracy and population density), as explanatory variables of per capita emissions of a number of pollutants including $\mathrm{CO}_{2}$. Their results show an increase of $\mathrm{CO}_{2}$ emissions per capita for all income levels, contradicting the Kuznets' curve hypothesis, while trade openness does not show a clear significance. 
In a more recent application to the case of China, income per capita does not have any significant impact on $\mathrm{CO}_{2}$ emissions per capita, whereas trade openness is found to have a significant positive effect on emissions (Ang, 2009). Local R\&D intensity and distance to the technological frontier (measured as the difference of US and China TFP) significantly reduces emissions, independently and as an interaction variable. The significance of the interaction term highlights the importance of local absorptive capacity to assimilate foreign technical know-how. A dummy variable for environmental regulation also shows a significant effect of tougher environmental regulation in decreasing emissions per capita. The results indicate that the scale and composition effects of trade have outweighed the technique effect. However, the beneficial impact of more efficient foreign technologies can be harnessed with local R\&D and is higher the larger the distance to the frontier.

\section{Business insights}

\subsection{The business approach to climate change $\boldsymbol{T}$}

The private sector owns most of the technologies required for a shift to low-carbon paths and will deliver the largest share of TT to developing countries. Econometric studies have so far been unable to explain why some countries are more effective in attracting foreign technologies that lead to emissions reductions. The UNFCCC process could benefit from understanding the conditions that enhance private investment and the processes that facilitate knowledge spillovers.

The academic business literature has focused on three main themes related to the internationalization of technology: the technological impact of technologically superior foreign-owned companies, which have higher productivity than indigenous firms; the association of FDI with technology gaps between countries and how FDI can narrow these gaps; and the role of TNC as technology creators across national boundaries (Cantwell, 2009).

In the field of climate change technologies, two types of evidence-based studies provide insights into the factors that enhance private TT. First, business organizations provide a business perspective on climate change TT through consensus-based reports (ICC, 2008; ACTI, 2009; WBCSD, 2010). Second, the case study literature offers a micro-level perspective of the processes of transferring and adopting technologies (Forsyth, 2005; Lewis, 2007; Ockwell et al., 2008; Cai et al., 2009; Gboney, 2009; Grant, 2009; Machado, 2009; Wang, 2009; Zhang et al., 2009; Hultman et al., forthcoming; Lewis, 2010).

The private sector understands TT as a by-product of day-to-day commercial operations, such as equipment sales, leases, services or procurement contracts, joint ventures, licensing agreements or investments. The private sector, as well as other institutions (IEA, 2010), prefers to use the concept of technology diffusion (WBCSD, 2010), which is understood as a way to grow, earn profit and survive. It is noted in the international business literature that technology encompasses not only the scientific and engineering knowledge and blueprints that usually result from R\&D activities, but also the corporate capacity to operationalize this knowledge and use it in production (Cantwell, 2009). Although codified knowledge and blueprints can be transferred, corporate technological capabilities cannot be transferred through market exchanges. Instead they must be internally learned. As a result, the management literature has shifted its focus away from the TT role of TNCs to their role as technology creators and innovators through cross-border networks (Cantwell, 2009).

Businesses do not have a specific interest in measuring technology diffusion, but are interested in measuring investments and economic returns. Operating indicators (installed capacity or annual production in foreign markets) or economic data (investments, $R \& D$ expenditure, revenues, profits in foreign markets) are used to reflect the extent of technology diffusion. Companies only account for 
emission reductions per technology if they need to perceive some economic compensation (carbon credits) or comply with emissions trading schemes or carbon accounting initiatives.

TT to developing countries is not a particular activity for the private sector (WBCSD, 2010). Highquality cleaner technologies are being continuously deployed in developing countries, when they make economic sense; they provide a strategic fit and involve a level of risk that is commensurate to the projected returns. Businesses operate in competitive environments, with some developing countries providing technologies that compete in local and international markets. Knowledge acquired through experience and $R \& D$ investment provides a competitive advantage, and business understands that it cannot be shared without sufficient compensation.

\subsection{National strategies}

The main driver for private international TT is the prospect of a large and stable demand and long-term profits. Successful TT by private companies does not usually happen under artificial conditions of subsidies and grants, which may create short-term and unsustainable economic conditions (Forsyth, 2005). Carbon credits via the CDM have facilitated further technology diffusion by reducing the payback period and increasing projects' internal rate of return (IRR). However, several authors have shown that successful TT through the CDM has been based on pre-existing enabling frameworks in recipient countries. For example, Hansen (2008) has observed that transfers of biomass and biogas technologies to Malaysia through the CDM were done by foreign companies that already had a strong presence in the Malaysian market. Several studies of TT in Chinese CDM projects have shown that certified emissions reductions income was rarely, due to the uncertainty of carbon income and the long CDM registration time lags, the primary reason why the projects were developed (Wang, 2009; Lewis, 2010). A study based in India and Brazil demonstrated that managers considering investments in the CDM tended to favour projects that were non-additional or only marginally additional, due to the uncertain future revenue streams of the carbon market and the certain immediate costs (Hultman et al., forthcoming). Furthermore, the success of Chile in attracting CDM projects has been attributed to its export-oriented, open and liberalized economy, political stability and business-friendly politics (Rindefjäll et al., 2010).

The business community agrees, based on its experience, that five elements provide the enabling frameworks for investments and sales of low-carbon technologies: strong government signals, adequate institutional frameworks, appropriate absorptive capacity, economic and financial incentives, and energy efficiency drivers (WBCSD, 2010). These elements are backed up by the case study literature.

China, India and Brazil have been the most successful developing countries to absorb foreign technologies, deploy renewable technologies and grow domestic renewable energy industries. This success stems from a large internal demand and growth potential, together with strong signals and incentives from their governments favouring low-carbon growth. In India, the Electricity Act of 2003 proposed renewable energy targets and policy support mechanisms, including feed-in-tariffs. In China, the Renewable Energy Law included a mandatory renewable market share, a wind concession programme, premiums to renewable power, VAT relief for renewable energy technologies, emission limits for new vehicles (stricter than those in the US) and timetables for the closure of inefficient production facilities. The Brazilian government started promoting ethanol distilled from sugar cane in the 1970s with the Brazilian Alcohol Programme, which triggered technological developments in the automotive industry (Ockwell et al., 2008; Ribeiro and De Abreu, 2008).

Adequate institutional frameworks are essential to ensure that strong signals, regulations and incentives are properly implemented. This includes stable policies, transparent investment regulation and conducive local conditions (WBCSD, 2010). For certain technologies an important element is the establishment of appropriate IPR protection to enhance the transfer of technologies (ACTI, 2009). 
Indeed, uncoordinated energy policies, uncertainty of institutional frameworks, excessive bureaucracy or inappropriate power purchase agreements are behind some TT failures in Ghana and South Africa (Gboney, 2009; Grant, 2009).

Furthermore, a minimum threshold of human capital and infrastructures is required for the efficient operation of transferred technologies and the subsequent generation of advanced local technological capabilities. This requires a functioning education system, targeted capacity-building programmes, and capacity at all levels of implementation of the technologies: technical, financial, business development and regulation (Gboney, 2009; WBCSD, 2010).

Government support to infant domestic industries has also been behind the technological success of India and China (Lewis, 2007; Wang, 2009; Zhang et al., 2009). Both countries have adapted customs duties and related taxes to promote the use of domestically manufactured wind turbines. However, India has been much more hands-off than China. The latter has placed a local content requirement on all developers for the concession of wind projects, mandating that $70 \%$ of the turbine content is made in China. In addition, Chinese-owned manufacturers have been the most selected by the government in the concession of permits for projects. This has forced many wind turbine manufacturers to localize their manufacturing facilities. The localization policy has been highly successful, with domestic and joint venture manufacture accounting for $62 \%$ of total installed capacity in 2008 . Yet, many of the foreign-owned companies have opted to partner with Chinese-owned companies only for some smaller components and have not transferred know-how or IPR. An efficiency differential between foreign and local technologies of around 30\% confirms this knowledge gap (Wang, 2009). Also, when the most easily accessible renewable resources are exhausted, more sophisticated technologies are needed, usually in the hands of developed country companies reluctant to give up or put at risk their strategic knowledge assets. The Chinese government has also supported the bargaining power of local industries and lowered costs and risks, acting as a broker in facilitating transfers of technology at the demonstration stage (Wang, 2009).

\subsection{Company strategies}

In addition to government support, appropriate business strategies to acquire and absorb foreign technologies are essential for building successful local industries. It is noted in the management literature that the absorptive capacity of recipient firms is a necessary condition for beneficial spillovers to occur as a result of TT activities (Cantwell, 2009). Local industries with a strong technological tradition are able to catch up with technologically superior foreign-owned companies. Hence, the more innovative a local company is, the more favourable the effects of FDI will be and the easier it will be to attract such investment (Cantwell, 2009).

Some successful cases of TT include Chinese and Indian wind turbine manufacturers, and Chinese cement waste heat power generation, all of which have used technologies originating in foreign countries to develop innovative local industries.

The most common climate change TT mechanisms have been licensing, joint development and acquisition of foreign companies. For example, the leading Chinese wind turbine manufacturer, Goldwind, produced its first $660-750 \mathrm{~kW}$ turbines using a licence from a German company, and its $1.5 \mathrm{MW}$ turbines in joint development with another German company, which it subsequently acquired to produce the most advanced 2.5-5 MW models. Goldwind actively pursues patenting for all new products to ensure market power (Lewis, 2007; Wang, 2009; Zhang et al., 2009). Suzlon, the leading Indian wind turbine manufacturer, wind farm project developer and operator, built its capacity upon licensing agreements complemented with internal R\&D. Suzlon located R\&D centres at knowledge hubs in Germany and the Netherlands, and its international headquarters in Denmark. The company also 
acquired foreign manufacturers of generators, gearbox and wind turbines (Lewis, 2007). Cement waste heat power generation technology was introduced in China with government brokerage, through a joint venture between a Chinese company and a Japanese technology provider. The Chinese company obtained the production licence for the technology and became a domestic technology provider offering a low-cost version, which facilitated large-scale deployment (Wang, 2009).

IPR did not constitute a barrier to the rapid development of endogenous capacity in any of the cases reviewed, given the wide range of technology suppliers that were willing to license. Usually, technology leaders lack incentives to license proprietary information to developing country companies that could become their competitors. Instead, developing country companies tend to rely on licensing from well-established but second-tier companies that have more to win and less risk from licence fees than from risky FDI in unknown markets (Lewis, 2007).

Local companies compensate for their products' lower efficiency by offering costs significantly lower than foreign technologies. This allows them to bid for additional capacity and improve through learning-by-doing. This process is possible in countries with a large market scale. The result is a higher number of competitors, lower market power of foreign companies and lower cost of reducing GHG emissions, with the subsequent global welfare gains.

\section{Conclusions}

Some limitations of the reviewed evidence-based literature should be highlighted before drawing policy conclusions. First, econometric studies of climate change TT have not yet been able to link flows of climate change-related technologies to their effects in reducing GHG emissions. Further research is needed to better understand the factors that improve the extent of knowledge spillovers through transfers of climate change technologies. This requires disaggregated data on climate change specific trade and FDI. Second, although most of the case study literature on TT to developing countries focuses on the Chinese and Indian experiences, China and India do not represent typical developing country economies. Both offer potential investors the prospect of large profits and have an advanced domestic technological base that allows rapid adoption of foreign technologies. Smaller developing countries will struggle to replicate the Chinese and Indian success stories, given their small bargaining power towards foreign technology providers and their lower internal technological capabilities. Further case study research is needed to identify the national policies and business strategies that have worked or failed in non-BRIC economies.

Despite these caveats, the evidence-based literature provides valuable insights into how the UNFCCC approach to climate change mitigation TT to developing countries might be improved. Recommendations are provided for each of the gaps identified in Section 3.3:

1. Bring the UNFCCC process closer to the enabling frameworks that facilitate private sector investment: Evidence provided by the case study literature demonstrates that the UNFCCC mechanisms have played a limited role in promoting TT. The private sector, which owns and is responsible for most climate change TT, is greatly attracted to the stable potential profits of large and growing markets. It chooses to locate in countries with strong fundamentals (human capital, stable macroeconomic conditions, infrastructure) and solid national support for low-carbon development, through clear national renewable energy and efficiency targets and related regulations and economic incentives. Supportive policies also require strong institutions to be effectively implemented.

IPR protection is necessary to attract foreign activity. IPR have not constituted a barrier for rapid development of local capacity in countries with technological capabilities as foreign technology 
owners have been willing to transfer their knowledge in exchange for a fair compensation. In addition, strong IPR enforcement helps emerging countries to capitalize on their innovations and sends the right signal to foreign investors considering locating knowledge-intensive production plants in their territories.

Local businesses adopting foreign technologies need strong business and technological capabilities to be able to translate foreign knowledge into local technological change. They need to be involved in active learning processes and continue to carry out $R \& D$ activities to be able to identify the best foreign technology, bargain for the lowest possible cost and adapt it to local circumstances.

Given the importance of such national enabling environments, the role of an international agreement should be to facilitate ambitious national commitments that are reflected in national action. Individual developing country action would not be expected, even with increasing income levels, because climate change is a global externality. An international agreement with clear long-term emission reduction targets would therefore provide the strong signals required by the private sector. Uncertainty and the absence of a carbon price would instead delay investments in lowcarbon technologies, which are more expensive than incumbent technologies when the cost of carbon is not internalized. The activities of the TM should be integrated in national planning processes, facilitating the design, funding and implementation of policies that promote the diffusion and local adoption of climate change technologies.

2. Recognize the diversity of the developing world and design TT policies adapted to each country circumstances: Evidence shows that the group of non-Annex I countries is highly heterogeneous. Each country has different technological needs depending on its size, income level, growth rate, stage of development, productive structure and technological capabilities. Targeted policies to enhance climate change TT would maximize the impact on GHG emissions reductions.

Large developing countries with relatively high technological capabilities receive the largest absolute TT flows, but are less dependent on foreign technologies than smaller and poorer countries. BRIC countries have developed endogenous capabilities and are able to produce, use, maintain and adapt many low-carbon technologies with their own resources. These larger countries still need to transfer the most innovative technologies, but have in many cases themselves become providers of mature technologies for other developing countries.

Given their status as main GHG emitters in the developing world and their high technological capabilities, the priority for BRIC countries is to build a significant scale of low-carbon production at a low cost. The higher cost of low-carbon technologies relative to incumbent technologies could be balanced through national and international policies that recognize the cost of carbon. Scaling up low-carbon technologies in emerging economies will also lead to cost reductions through learning-by-doing and economies of scale (Stern, 2007). Taking advantage of knowledge already available in developed countries through climate change TT saves significant amounts of $R \& D$ investments for developing countries. Open trade and FDI policies that facilitate the flow of foreign technologies need to specifically target climate change-related technologies and come together with increased environmental awareness and related regulations. Otherwise, the scale and composition effects of foreign flows may outweigh the technique effect and lead to increased GHG emissions.

In contrast, small and poor countries with low technological capabilities receive low TT flows but depend more highly on foreign technologies to reduce their carbon intensity. The marginal return of investments in local $R \& D$ and education is greater for countries that are further from the international best-practice frontier. These countries are responsible for a very small share of global GHG emissions. Their priority should be to improve local technological capabilities as a precondition of open trade and FDI policies that can support low-carbon development paths. 
There is a large spectrum of countries at different stages of development that lie between the large developing countries, with relatively high technological capabilities, and the small and poor countries. These countries may have significant technological capabilities but, due to their demand size and growth potential, are unable to compete with Brazil, India and China for foreign capital. They could engage in regional technological cooperation to identify similar needs around specific technologies. Bundling TT needs would create larger opportunities for the business usually attracted to the larger BRIC markets (WBCSD, 2010). Given their limited resources and demand size, small countries should identify their areas of competitive advantage to develop a local climate change technology base with the support of foreign TT. Competitive advantage can come from the availability of natural resources, a competitive industrial base or highly skilled human resources. It can be enhanced through technology-push policies such as targeted R\&D and specific training on low-carbon technologies. However, a significant local market is also needed and can be promoted through demand-pull policies that recognize the cost of carbon.

3. Measure perfornance of TT policies to decide the allocation of technology funds: Further research is necessary to improve the understanding of the drivers of TT. New econometric models that link climate change technology flows to changes in absolute and relative GHG emissions could inform UNFCCC assessments of the long-term effectiveness of TT policies. Such models would enable measurements of both the importance of foreign technologies for the reduction of carbon intensity in different countries and the effectiveness of different countries in translating foreign flows of climate change technology into actual emissions reductions. The determinants of successful TT could be identified and used to define funding priorities for different countries.

Additionally, a thorough study of operational TT indicators would enable short-term evaluation of TT policies. Indicators should focus on the TT drivers identified through economic models and include business data (such as installed capacity, annual production or investment in foreign markets) as well as indicators of potential spillovers (such as number of local employees per qualification, number of training courses, number of foreign licences, number and revenue of local providers).

\section{Notes}

1. As declared by Nitin Desai, from the Indian delegation in 'When Two's Company', Times of India, 4 January 2010.

2. The term 'BRIC countries' was coined by the firm Goldman Sachs to refer to Brazil, Russia, India and China as a group of large and fast growing economies.

\section{References}

ACTI, 2009, Policies for Clean Technology Innovation and Dissemination, Alliance for Clean Technology Innovation.

Ang, J.B., 2009, ' $\mathrm{CO}_{2}$ emissions, research and technology transfer in China', Ecological Econonics 68(10), 2658-2665.

Archibugi, D., Coco, A., 2004, 'A new indicator of technological capabilities for developed and developing countries (ArCo)', CEIS Research Paper 44, Tor Vergata University, CEIS

Bell, M., 1997, 'Technology transfer to transition countries: are there lessons from the experience of the post-war industrializing countries?', in: D.A. Dyker (ed), The Technology of Transition: Science and Technology Policies for Transition Countries, Central European University Press, Budapest, Hungary, 63-94. 
Blalock, G., Gertler, P.J., 2009, 'How firm capabilities affect who benefits from foreign technology', Joumal of Development Economics 90(2), 192-199.

Borensztein, E., De Gregorio, J., Lee, J.W., 1998, 'How does foreign direct investment affect economic growth?' Joumal of Intemational Economics $45(1), 115-135$.

Brewer, T.L., 2008, 'Climate change technology transfer: a new paradigm and policy agenda', Climate Policy $8(5)$, $516-526$.

Brewer, T.L., 2009, 'Technology transfers and climate change: international flows, barriers and frameworks', in: L. Brainard, I. Sorkin (eds), Climate Change, Trade, and Competitiveness: Is a Collision Inevitable?, The Brookings Institution, Washington, DC.

Cai, W., Wang, C., Liu, W., Mao, Z., Yu, H., Chen, J., 2009, 'Sectoral analysis for international technology development and transfer: cases of coal-fired power generation, cement and aluminium in China', Energy Policy 37(6), 2283-2291.

Cannady, C., 2009, Access to Climate Change Technology by Developing Countries - A Practical Strategy, Issue Paper No. 25, Intellectual Property and Sustainable Development Series, Global Platform on Climate Change, Trade Policies and Sustainable Energy, International Centre for Trade and Sustainable Development (ICTSD), Geneva.

Cantwell, J., 2009, 'Innovation and information technology in the MNE', in: A.M. Rugman (ed), The Oxford Handbook of International Business, Oxford University Press, Oxford, 431-456.

Coe, D.T., Helpman, E., 1995, 'International R\&D spillovers', European Economic Review 39(5), 859-887.

Cole, M.A., 2006, 'Does trade liberalisation increase national energy use?', Economics Letters 92(1), 108-112.

Cole, M.A., Elliott, R.J.R., 2003, 'Determining the trade-environment composition effect: the role of capital, labor and environmental regulations', Joumal of Environmental Economics and Management 46(3), 363-383.

Dechezleprêtre, A., Glachant, M., Ménière, Y., 2008, 'The Clean Development Mechanism and the international diffusion of technologies: an empirical study', Entergy Policy 36(4), 1273-1283.

Dechezleprêtre, A., Glachant, M., Ménière, Y., 2010, What Drives the International Transfer of Climate Change Mitigation Technologies? Empirical Evidence from Patent Data, Nota di Laboro 12.2010, Fondazione Eni Enrico Mattei, Milan.

Devereux, M.P., Griffith, R., 1998, Taxes and the location of production: evidence from a panel of US multinationals', Joumal of Public Economics 68(3), 335-367.

Dinopoulos, E., Segerstrom, P., 2010, 'Intellectual property rights, multinational firms and economic growth', Joumal of Development Economics 92(1), 13-27.

Doranova, A., 2009, 'Technology transfer and learning under the Kyoto Regime: exploring the technological impact of CDM projects in developing countries', PhD thesis, Maastricht University, Maastricht.

Eaton, J., Kortum, S., 1999, 'International patenting and technology diffusion: theory and measurement', International Economic Review 40, 537-70.

Eaton, J., Kortum, S., 2002, 'Technology, geography, and trade', Econometrica 70(5), 1741-1779.

Ferrantino, M.J., 1993, 'The effect of intellectual property rights on international trade and investment', Review of World Economics 129(2), 300-331.

Forsyth, T., 2005, 'Enhancing climate technology transfer through greater public-private cooperation: lessons from Thailand and the Philippines', Natural Resources Forum 29(2), 165-176.

Frankel, J.A., Rose, A.K., 2002, Is Trade Good or Bad for the Environment? Sorting Out the Causality, Working Paper No. 9201, National Bureau of Economic Research, Cambridge.

Gboney, W., 2009, 'Policy and regulatory framework for renewable energy and energy efficiency development in Ghana', Climate Policy 9(5), 508-516.

Glass, A.J., Saggi, K., 2002, 'Intellectual property rights and foreign direct investment', Journal of International Economics $56(2), 387-410$.

Grant, K., 2009, 'Concentrated solar power in South Africa', Climate Policy 9(5), 544-552.

Grubb, M., 2010, 'Copenhagen: back to the future?' Climate Policy 10(2), 127-130.

Hansen, U.E., 2008, Technology and knowledge transfer from Annex I countries to Non-Annex I countries under the Kyoto Protocol's Clean Development Mechanism (CDM) - an empirical case study of CDM projects implemented in Malaysia', Master's thesis, Department of Geography and Geology, University of Copenhagen, Copenhagen. 
Haščič, I., Johnstone, N., 2009, 'The Kyoto Protocol and International Technology Transfer: an empirical analysis using patent data', 17 th Annual Conference of the European Association of Environmental and Resource Economists (EAERE), VU University Amsterdam, 24-27 June 2010.

Helpman, E., 1993, 'Innovation, imitation and Intellectual Property Rights', Econometrica 61(6), 1247-1280.

Hines, J.R., 1996, 'Altered states: taxes and the location of foreign direct investment in America', American Economic Review 86(5), 1076-1094.

Hübler, M., Keller, A., 2010, 'Energy savings via FDI? Empirical evidence from developing countries', Environment and Development Economics 15, 59-80.

Hultman, N.E., Pulver, S., Guimaraes, L., Deshmukh, R., Kane, J., forthcoming, 'Carbon market risks and rewards: firm perceptions of CDM investment decisions in Brazil and India', Energy Policy.

ICC, 2008, Technology Development and Deployment to Address Climate Change - For the UNFCCC 14th Conference of the Parties (COP) Meeting in Poznan, Poland, Discussion Paper No. 213/61, International Chamber of Commerce, Paris.

IEA (International Energy Agency), 2010, Energy Technology Perspectives 2010: Scenarios \& Strategies to 2050, Organisation for Economic Co-operation and Development/International Energy Agency, Paris.

IISD, 2006, Summary of the Twelfth Conference of the Parties to the UNFCCC and Second Meeting of the Parties to the Kyoto Protocol, Earth Negotiations Bulletin 12(318), International Institute for Sustainable Development, Winnipeg, Manitoba, Canada.

IPCC (Intergovernmental Panel on Climate Change), 2000, Methodological and Technological Issues in Technology Transfer: Special Report of Working Group III of the Intergovernmental Panel on Climate Change, Cambridge University Press, Cambridge.

Javorcik, B.S., Spatareanu, M., 2008, 'To share or not to share: does local participation matter for spillovers from foreign direct investment?', Joumal of Development Economics 85(1-2), 194-217.

Kabiraj, T., Mariit, S., 1993, 'International technology transfer under potential threat of entry - a Cournot-Nash framework', Joumal of Development Economics 42(1), 75-88.

Keller, W., 2004, 'International technology diffusion', Joumal of Economic Literature 42(3), 752-782.

Kuo, C.C., Yang, C.H., 2008, 'Knowledge capital and spillover on regional economic growth: evidence from China', China Economic Review 19(4), 594-604.

Lee, J., 2009, 'Trade, FDI, and productivity convergence: a dynamic panel data approach in 25 countries', Japan and the World Economy 21(3), 226-238.

Lee, J.Y., Mansfield, E., 1996, 'Intellectual property protection and US foreign direct investment', Review of Econonics and Statistics 78(2), 181-186.

Lewis, $\mathbf{J} ., 2007$, 'Technology acquisition and innovation in the developing world: wind turbine development in China and India', Stulies in Comparative International Development (SCID) 42(3), 208-232.

Lewis, J.I., 2010, 'The evolving role of carbon finance in promoting renewable energy development in China', Energy Policy 38(6), 2875-2886.

Liao, H.L., Liu, X.H., Holmes, M., Weyman-Jones, T., 2009, 'The impact of foreign R\&D on total factor productivity in the East Asian manufacturing industry', Manchester School 77(2), 244-270.

Machado, H., 2009, 'Brazilian low-carbon transportation policies: opportunities for international support', Climate Policy 9(5), 495-507.

Mallett, A., Ockwell, D.G., Pal, P., Kumar, A., Abbi, Y.P., Haum, R., Mackerron, G., Watson, J., Sethi, G., 2009, UK-India Collaborative Study on the Transfer of Low Carbon Technology: Phase II Final Report, Science and Technology Policy Research, Institute of Development Studies, University of Sussex and The Energy and Resources Institute (TERI), New Delhi.

Mansfield, E., Romeo, A., 1980, 'Technology-transfer to overseas subsidiaries by United-States based firms', Quarterly Journal of Economics 95(4), 737-750.

Marcellino, D., Gerstetter, C., 2010, Technology Transfer in the Intemational Climate Negotiations, Assessment of Proposals and Discassion of Open Questions, Ecologic Institute, Washington, DC.

Mielnik, O., Goldemberg, J., 2002, 'Foreign direct investment and decoupling between energy and gross domestic product in developing countries', Energy Policy 30(2), 87-89.

Ockwell, D.G., Watson, J., MacKerron, G., Pal, P., Yamin, F, 2008, 'Key policy considerations for facilitating low carbon technology transfer to developing countries', Entrgy Policy 36(11), 4104-4115. 
Peterson, S., 2008, 'Greenhouse gas mitigation in developing countries through technology transfer? A survey of empirical evidence', Mitigation and Adaptation Strategies for Global Change 13(3), 283-305.

Popp. D., 2008, International Technology Transfer for Climate Policy, Policy Brief No. 39/2009, Center for Policy Research, Maxwell School of Citizenship and Public Affairs, Syracuse University, Syracuse, NY.

Ramondo, N., 2009, 'Foreign plants and industry productivity: evidence from Chile', Scandinavian Joumal of Economics 111(4), 789-809.

Ribeiro, S.K., De Abreu, A.A., 2008, 'Brazilian transport initiatives with GHG reductions co-benefit', Climate Policy $8(2), 220-240$.

Rindefjäll, T., Lund, E., Stripple, J., 2010, Wine, Fruit and Emission Reductions: CDM as Development Strategy in Chile, Working Paper No. 004, The Governance of Clean Development, University of East Anglia, Norwich, UK.

Saggi, K., 2004, Intemational Technology Transfer to Developing Countries, Commonwealth Secretariat, London.

Schneider, M., Holzer, A., Hoffman, V.H., 2008, 'Understanding the CDM's contribution to technology transfer', Energy Policy 36(8), 2930-2938.

Seres, S., Haites, E., Murphy, K., 2009, 'Analysis of technology transfer in CDM projects: an update', Entergy Policy $37(11), 4919-4926$.

Seres, S., Haites, E., Murphy, K., 2010, The Contribution of the Clean Development Mechanism under the Kyoto Protocol to Technology Transfer, Document for the United Nations Framework Convention for Climate Change, Bonn [available at http://cdm.unfccc.int/Reference/Reports/TTreport/TTrep10.pdf].

Staley, B.C., Freeman, C., 2009, Tick Tech Tick Tech: Coming to Agreement on Technology in the Countdown to Copenhagen, Working Paper, World Resources Institute, Washington, DC.

Stern, N.H., 2007, The Economics of Climate Change: the Stem Review, Cambridge University Press, Cambridge.

South Center and CIEL, 2008, 'The technology transfer debate in the UNFCCC: politics, patents and confussion', Intellectual Property Quarterly Update, Fourth Quarter.

UNCTAD (United Nations Conference on Trade and Development), 2010, World Investment Report 2010: Investing in a Low-Carbon Econony, United Nations Conference on Trade and Development, Geneva.

UNDP (United Nations Development Programme), 2009, Handbook for Conducting Technology Needs Assessment for Climate Change, UNDP, New York, NY.

UNEP Risoe, 2010, The CDM Pipeline, United Nations Environment Programme Risoe Centre on Energy, Climate and Sustainable Development, Roskilde, Denmark [available at www.cdmpipeline.org].

UNFCCC, 2009a, Recommendations on Future Financing Options for Enhancing the Development, Deployment, Diffusion and Transfer of Technologies under the Convention, FCCC/SB/2009/2, Subsidiary Body for Science and Technological Advice, UNFCCC Secretariat, Bonn.

UNFCCC, 2009b, Performance indicators to monitor and evaluate the effectiveness of the implementation of the technology transfer framework, FCCC/SB/2009/4, United Nations Framework Convention on Climate Change Secretariat, Bonn.

UNFCCC, $2009 \mathrm{c}$, Strategy paper for the long-term perspective beyond 2012, including sectoral approaches, to facilitate the development, deployment, diffision and transfer of technologies under the Convention, FCCC/SB/2009/3, United Nations Framework Convention on Climate Change Secretariat, Bonn.

UNFCCC, 2010a, Report on the Review and Assessment of the Effectiventess of the Implementation of Article 4, Paragraphs 1 (C) and 5, of the Convention - Note by The Secretariat, Subsidiary Body for Implementation FCCC/SBI/2010/ INF.4, Bonn.

UNFCCC, 2010b, Report of the Conference of the Parties on its fiftenth session, held in Copenhagen from 7 to 19 December 2009. Addendum. Part Two: Adtion taken by the Conference of the Parties at its fifteenth session, $\mathrm{FCCC} / \mathrm{CP} / 2009 / 11 /$ Add.1, UNFCCC Secretariat, Bonn.

Vadlamannati, K.C., Tamazian, A., 2009, 'Growth effects of FDI in 80 developing economies: the role of policy reforms and institutional constraints', Joumal of Economic Policy Reform 12(4), 299-322.

Wang, B., 2009. Can the CDM Bring Technology Transfer to Developing Countries? An Empirical Study of Technology Transfer in China's CDM Projects, Working Paper No. 002, The Governance of Clean Development, University of East Anglia, Norwich, UK.

Wara, M., 2009, 'The clean development mechanism's early performance', in: S. Schneider, A. Rosencrantz, M. Manstrandrea (eds), Climate Change Science and Policy, Island Press, Washington, DC.

WBCSD, 2010, Enabling Frameworks for Technology Diffision: a Business Perspective, World Business Council for Sustainable Development, Geneva. 
WBCSD (World Business Council for Sustainable Development), Climate Focus and Ecofys, 2010, Private Sector and the UNFCCC: Options for Institutional Engagenent, Competitiveness and Innovation Framework Programme, European Commission, Brussels.

Wei, L., 1995, 'International technology transfer and development of technological capabilities: a theoretical framework', Technology in Society 17(1), 103-120.

World Bank, 2008, Global Economic Prospects 2008: Technology Diffusion in the Developing World, World Bank, Washington, DC.

World Bank, 2009, World Development Report 2010: Development and Climate Change, World Bank, Washington, DC. WRI, 2009, Summary of UNFCCC Submissions, WRI, Washington, DC.

$\mathrm{Xu}, \mathrm{B} ., 2000$, 'Multinational enterprises, technology diffusion, and host country productivity growth', Journal of Development Economics 62(2), 477-493.

$\mathrm{Xu}, \mathrm{X} . \mathrm{H}$, 2008, 'FDI technology spillovers positively determined from human resources capital', in: H.Y. Yin, B. Cui, R. Chen (eds), Modem Finance and Global Trading Cooperation: Proceedings of the 5th International Anmual Conference on WTO and Financial Engineering, Hangzhou, 18-20 May 2008, Orient Acad Forum, Marrickville, New South Wales, Australia.

$\mathrm{Xu}, \mathrm{B}$., Wang, J.M., 1999, 'Capital goods trade and R\&D spillovers in the OECD', Canadian Joumal of Economics 32(5), $1258-1274$.

Yin, Z., Ding, R.J., 2009, 'Heterogeneous human capital, FDI spillover and energy efficiency in China', in: F.G. Duserick (ed), Eighth Wuhan International Conference on E-Business, Vol. I-III, Wuhan, China, 30-31 May 2009, Alfred University Press, Alfred, NY, 1654-1660.

Zhang, X.L., Chang, S.Y., Huo, M.L., Wang, R.S., 2009, 'China's wind industry: policy lessons for domestic government interventions and international support', Climate Policy 9(5), 553-564. 